\title{
Synthesis, Crystal structure and Characterization of a New Oxalate Chromium (III) Complex
}

\author{
RIHAB DRIDI*, SAOUSSEN CHERNI and MOHAMED FAOUZI ZID \\ Laboratoire de Matériaux et Cristallochimie, Département de Chimie, Faculté des Sciences de Tunis, \\ Université de Tunis El Manar, 2092 Tunis, Tunisie \\ e-mail: rihab018@live.fr
}

MS received 20 February 2015; revised 17 May 2015; accepted 18 May 2015

\begin{abstract}
A new hybrid salt $\left(\mathrm{C}_{5} \mathrm{H}_{9} \mathrm{~N}_{2}\right)\left[\mathrm{Cr}\left(\mathrm{C}_{2} \mathrm{O}_{4}\right)_{2}\left(\mathrm{H}_{2} \mathrm{O}\right)_{2}\right] \cdot 3 \mathrm{H}_{2} \mathrm{O}, 3,5$-dimethylpyrazole Cis diaquadioxalatochromate(III) trihydrate, has been prepared by slow evaporation at room temperature and characterized by single crystal X-ray diffraction, IR, UV-visible spectroscopies, PXRD and thermogravimetric analyses. Furthermore, the observed crystal morphology was compared to the simulated one using the Bravais-Friedel, Donnay-Harker model. The structure of the title compound consists of $\left[\mathrm{Cr}\left(\mathrm{C}_{2} \mathrm{O}_{4}\right)_{2}\left(\mathrm{H}_{2} \mathrm{O}\right)_{2}\right]^{-}$mononuclear anions, 3,5-dimethylpyrazole cations and three uncoordinated water molecules. $\mathrm{The}_{\mathrm{Cr}}{ }^{3+}$ ion is six coordinated in a slightly distorted octahedral environment, by two $\mathrm{O}$ atoms from two water molecules and four $\mathrm{O}$ atoms of two oxalate anions acting as chelating ligands. The cohesion of the structure is established by intermolecular $\mathrm{O}-\mathrm{H} . . . \mathrm{O}, \mathrm{N}-\mathrm{H} . . . \mathrm{O}$ hydrogen bonds which connect ionic entities and water molecules and also by $\pi-\pi$ stacking interactions between the rings of 3,5-dimethylpyrazole cations. Hence, both coordinated and uncoordinated water molecules play an important role in the hydrogen-bonding system and stabilize the structure.
\end{abstract}

Keywords. Chromium (III) complex; crystal structure; spectroscopic studies; thermal behavior.

\section{Introduction}

Recently, a variety of transition metal ions has been used to construct metal organic frameworks which are now attracting increasing interest not only for their versatile architectures but also for their potential applications in various fields such as catalysis, luminescence, magnetism and even industrial applications. ${ }^{1,2}$

On the other hand, the oxalate group continues to receive considerable attention due to its ability to transmit efficiently magnetic interactions through its bridging mode. ${ }^{3}$ Its planar shape, negative charge and good donor ability due to the presence of four oxygens, allow this ligand to act as a remarkably flexible ligand system upon complexation with different metal ions. In fact, this bidentate ligand has the ability to produce an array of new network architectures and to adopt various coordination modes. ${ }^{4}$ Moreover, the oxalate bridge can efficiently mediate the exchange interactions between paramagnetic metal ions, leading to interesting magnetic properties. $^{5}$

Up to now, there has been a significant interest in the synthesis and characterization of bis(oxalato) chromium (III) compounds through an impressive synthetic strategy based on supramolecular chemistry and

\footnotetext{
*For correspondence
}

self-assembly processes of two different components. Thus, to investigate new supramolecular architectures containing $\left[\mathrm{Cr}\left(\mathrm{C}_{2} \mathrm{O}_{4}\right)_{2}\left(\mathrm{H}_{2} \mathrm{O}\right)_{2}\right]^{-}$, we used pyrazole ring as organic cation which is considered as a convenient component for building up supramolecular systems and for participating in hydrogen bonding interactions. Due to the presence of $=\mathrm{NN}(\mathrm{H})$ fragment, this component possesses a unique ability to form various complexes with proton donor and proton acceptors. ${ }^{6,7}$ Additional stability can also be offered by $\pi-\pi$ stacking interactions of pyrazole rings. ${ }^{8}$ Therefore, a variety of complexes containing 3,5-dimethylpyrazole ligands has been synthesized and employed in coordination and organometallic chemistry ${ }^{9,10}$

As a part of our ongoing studies of new oxalate chromium (III) complex of general formula (organic cation) $\left[\mathrm{Cr}\left(\mathrm{C}_{2} \mathrm{O}_{4}\right)_{2}\left(\mathrm{H}_{2} \mathrm{O}\right)_{2}\right] \cdot \mathrm{nH}_{2} \mathrm{O}^{11}$ and in order to extend our studies in this field, we describe in the present work the synthesis, structure determination and characterization of a new bis(oxalato)chromate(III) complex.

\section{Experimental}

\subsection{Materials and Methods}

All reagents and solvents were obtained from commercial sources and used without further purification. 
The infrared spectra were recorded on a Perkin Elmer Spectrum BX spectrophotometer as $\mathrm{KBr}$ pellets, in $4000-400 \mathrm{~cm}^{-1}$ region on a Nicolet 470 FTIR spectrophotometer. The UV-visible absorption spectra were recorded on a 2802 UV/VIS spectrophotometer (UNICO) in the range $250-700 \mathrm{~nm}$. X-ray powder diffraction measurements were performed on a D8 ADVANCE BRUKER diffractometer using $\mathrm{Cu}$ $\mathrm{K}_{\alpha 1 / \alpha 2}$ radiations and equipped with Lynxeye accelerator. The Thermogravimetric and Differential Scanning Calorimetry (TGA-DSC) were carried out on a Setaram TG-DSC Labsys Evo thermal analyzer, under Ar at a heating rate of $10^{\circ} \mathrm{C} \mathrm{min}^{-1}$.

\subsection{Synthesis of the complex}

Aqueous solution of oxalic acid dihydrate $(2 \mathrm{mmol}$, $252.2 \mathrm{mg}$ ) and 3,5-dimethylpyrazole (1 mmol, 96.13 $\mathrm{mg}$ ) was added to $\mathrm{Cr}\left(\mathrm{NO}_{3}\right)_{3} .9 \mathrm{H}_{2} \mathrm{O}(1 \mathrm{mmol}, 400.15 \mathrm{mg})$ dissolved in $10 \mathrm{~mL}$ of water under continuous stirring at $323 \mathrm{~K}$. Slow evaporation of the resultant solution led to violet single crystals suitable for $\mathrm{X}$-ray diffraction after three weeks. Yield $=49 \%$.

\section{$2.3 X$-Ray crystallography}

A prismatic violet crystal $(0.56 \times 0.4 \times 0.32 \mathrm{~mm})$ was selected for the structural analysis. Diffraction data were collected at $298 \mathrm{~K}$ with Enraf-Nonius CAD4 automatic four-circle equipped with graphite monochromator using Mo $K_{\alpha}(\lambda=0.71073 \AA)$ radiation and with the $\omega-2 \theta$ scan mode. The structure was solved by Direct method and refined by full-matrix least squares method on $F^{2}$ using the SHELX-97 package. ${ }^{12}$ The non-hydrogen atoms were refined anisotropically. The hydrogen atoms of the water molecules were found in a difference Fourier map and refined with restraints: $\mathrm{d}(\mathrm{O}-\mathrm{H})=0.85(1) \AA, \mathrm{d}(\mathrm{H} . . . \mathrm{H})=1.387(2)$ $\AA$ and $U_{\text {iso }}(\mathrm{H})=1.5 U$ eq $(\mathrm{O})$. $\mathrm{H}$ atoms of the 3,5 dimethylpyrazole cation attached to carbon were placed in calculated positions with $\mathrm{C}-\mathrm{H}$ distance of $0.96-0.93$ $\AA$ while those attached to nitrogen were placed with $\mathrm{d}(\mathrm{N}-\mathrm{H})=0.86 \AA$. All were included as riding contributions with isotropic displacement parameters 1.2 - 1.5 times those of the attached atoms.

The final cycle of refinement converged to the values of $\mathrm{R}(\mathrm{F})=4.6 \%$ and $\mathrm{wR}\left(\mathrm{F}^{2}\right)=12.9 \%$. The molecular plots were drawn with the Diamond $3.0^{13}$ program. Crystal data, experimental details and refinement results of the crystal structure are summarized in table 1 .
Table 1. Crystal and structure refinement data for $\left(\mathrm{C}_{5} \mathrm{H}_{9} \mathrm{~N}_{2}\right)\left[\mathrm{Cr}\left(\mathrm{C}_{2} \mathrm{O}_{4}\right)_{2}\left(\mathrm{H}_{2} \mathrm{O}\right)_{2}\right] .3 \mathrm{H}_{2} \mathrm{O}$.

\begin{tabular}{|c|c|}
\hline Formula & $\mathrm{C}_{9} \mathrm{H}_{19} \mathrm{Cr} \mathrm{N}_{2} \mathrm{O}_{13}$ \\
\hline Formula weight & 415.26 \\
\hline Crystal system & Monoclinic \\
\hline Space group & $\mathrm{P} 2{ }_{1} / \mathrm{n}$ \\
\hline Volume $\left(\AA^{3}\right)$ & $1778.4(7)$ \\
\hline $\mathrm{Z}$ & 4 \\
\hline $\mathrm{a}(\AA)$ & $16.296(3)$ \\
\hline b $(\AA)$ & $7.103(2)$ \\
\hline$c(\AA)$ & $17.064(3)$ \\
\hline$\beta\left(^{\circ}\right)$ & $115.79(2)$ \\
\hline$\rho\left(\mathrm{gcm}^{-3}\right)$ & 1.551 \\
\hline$\mu\left(\mathrm{mm}^{-1}\right)$ & 0.71 \\
\hline$\theta$ range $\left(^{\circ}\right)$ & $2.3-26.96$ \\
\hline Index ranges & $\begin{array}{l}-20 \leq \mathrm{h} \leq 1,-9 \leq \mathrm{k} \leq 1, \\
-19 \leq 1 \leq 21\end{array}$ \\
\hline Total data collected & $465 \overline{5}$ \\
\hline Independent reflections & 3868 \\
\hline Reflections with I $>2 \sigma(\mathrm{I})$ & 3072 \\
\hline $\mathrm{R}_{\text {int }}$ & 0.019 \\
\hline Goodness-of-fit on $\mathrm{F}^{2}$ & 1.049 \\
\hline $\mathrm{R}[\mathrm{I}>2 \sigma(\mathrm{I})]^{\mathrm{a}}$ & 0.046 \\
\hline $\mathrm{wR}[\mathrm{I}>2 \sigma(\mathrm{I})]^{\mathrm{b}}$ & 0.129 \\
\hline Residuals $\left(\mathrm{e} \AA^{-3}\right)$ & 0.70 and -0.58 \\
\hline
\end{tabular}

\section{Results and Discussion}

\subsection{Crystal Structure of the complex}

The structure of the title compound is formed by one $\left(\mathrm{C}_{5} \mathrm{H}_{8} \mathrm{~N}_{2} \mathrm{H}\right)^{+}$cation, one $\left[\mathrm{Cr}(\mathrm{ox})_{2}\left(\mathrm{H}_{2} \mathrm{O}\right)_{2}\right]^{2-}$ anion, and three water molecules of crystallization (figure 1). The central atom of anion is hexacoordinated by two oxygen atoms from cis water molecules and four carboxylateoxygen atoms.

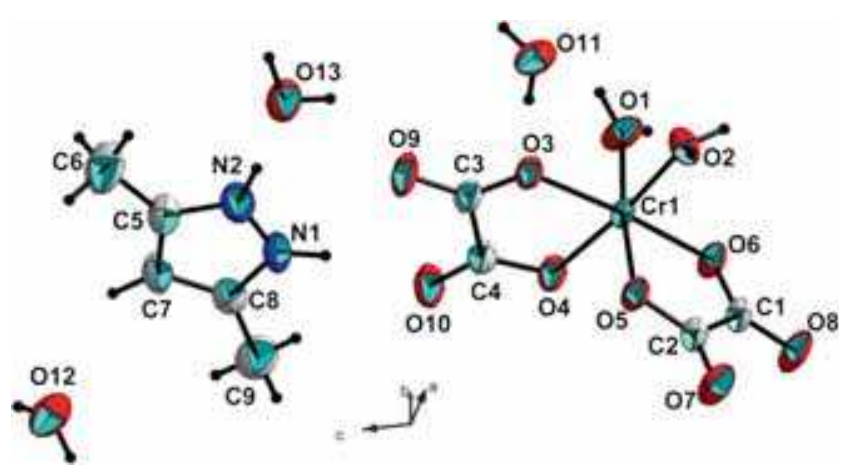

Figure 1. A view of the asymmetric unit with the atom numbering scheme. Displacement ellipsoids are drawn at the $50 \%$ probability level and $\mathrm{H}$ atoms are represented as spheres of arbitrary radius. 
The three diagonal angles of metal polyhedron $\left[173.53(7)^{\circ}\right.$ to $\left.175.20(7)^{\circ}\right]$ deviate from linearity, therefore the coordination geometry around $\mathrm{Cr}$ (III) atoms is a distorted octahedron built up by two $\mathrm{O}$ atoms $(\mathrm{O} 1, \mathrm{O} 2)$ from two cis water molecules and four $\mathrm{O}$ atoms $(\mathrm{O} 3$, $\mathrm{O} 4, \mathrm{O5}, \mathrm{O6})$ from two chelating oxalate dianions.

Because the coordination sphere is not a perfect octahedron, it is appropriate to use $\Sigma$ parameter, which is the sum of the deviation away from $90^{\circ}$ of the twelve possible $\mathrm{O}-\mathrm{Cr}-\mathrm{O}$ bite angles. As such, the value for an ideal octahedron is $\Sigma=0$, so that higher the value, the greater is the distortion. The formula used for the calculation is the following: ${ }^{14}$

$$
\sum=\sum_{i=1}^{12}\left|90-\alpha_{i}\right|
$$

In the case of this compound $\Sigma=32.52$ indicating a distorted octahedral geometry for the metal coordination sphere. The $\mathrm{O}-\mathrm{Cr}-\mathrm{O}$ bite angles $\left(88.80(7)^{\circ}\right.$ to $\left.95.71(7)^{\circ}\right)$ are far from the ideal one range from of $90^{\circ}$ because of the usual small bite size of five-membered planar chelate rings formed by the bidentate oxalate ligand. ${ }^{15,16}$ Selected bond lengths and angles are gathered in table 2.

The $\mathrm{Cr}-\mathrm{O}(\mathrm{ox})$ distances are very similar. They are comparable with the values reported for similar compounds containing the $\left[\mathrm{Cr}\left(\mathrm{C}_{2} \mathrm{O}_{4}\right)_{2}\left(\mathrm{H}_{2} \mathrm{O}\right)_{2}\right]^{-}$motif, completed with various uncoordinated cations, including quinolinium: $\left(\mathrm{C}_{9} \mathrm{H}_{8} \mathrm{~N}\right)\left[\mathrm{Cr}\left(\mathrm{C}_{2} \mathrm{O}_{4}\right)_{2}\left(\mathrm{H}_{2} \mathrm{O}\right)_{2}\right]$, 4-dimethylaminopyridinium: $\left(\mathrm{C}_{7} \mathrm{H}_{11} \mathrm{~N}_{2}\right)\left[\mathrm{Cr}\left(\mathrm{C}_{2} \mathrm{O}_{4}\right)_{2}\left(\mathrm{H}_{2} \mathrm{O}\right)_{2}\right]$, 4aminopyridinium: $\left(\mathrm{C}_{5} \mathrm{H}_{7} \mathrm{~N}_{2}\right)\left[\mathrm{Cr}\left(\mathrm{C}_{2} \mathrm{O}_{4}\right)_{2}\left(\mathrm{H}_{2} \mathrm{O}\right)_{2}\right] . \mathrm{H}_{2} \mathrm{O}$, and 1-ethyl-3-methylimidazolium (EMIm) $\left[\mathrm{Cr}\left(\mathrm{C}_{2} \mathrm{O}_{4}\right)_{2}\right.$ $\left.\left(\mathrm{H}_{2} \mathrm{O}\right)_{2}\right] \cdot{ }^{17-20}$

The $\mathrm{Cr}-\mathrm{O}$ (water) distance of 1.988(2) $\AA$ is somewhat longer than the $\mathrm{Cr}-\mathrm{O}$ (ox) ones, but significantly shorter than those for compounds already mentioned. The oxalate ligands do not show significant deviations from planarity. The dihedral angle between the two

Table 2. Selected bond lengths $(\AA)$ and angles $\left({ }^{\circ}\right)$.

\begin{tabular}{|c|c|c|c|}
\hline \multicolumn{4}{|l|}{ Bond lengths } \\
\hline $\mathrm{Cr} 1-\mathrm{O} 1$ & $1.975(2)$ & $\mathrm{Cr} 1-\mathrm{O} 4$ & $1.971(2)$ \\
\hline $\mathrm{Cr} 1-\mathrm{O} 2$ & $2.001(2)$ & $\mathrm{Cr} 1-\mathrm{O} 5$ & $1.964(2)$ \\
\hline $\mathrm{Cr} 1-\mathrm{O} 3$ & $1.972(2)$ & $\mathrm{Cr} 1-\mathrm{O} 6$ & $1.973(2)$ \\
\hline Bond angles & & & \\
\hline $\mathrm{O} 2-\mathrm{Cr} 1-\mathrm{O} 3$ & $90.98(7)$ & $\mathrm{O} 6-\mathrm{Cr} 1-\mathrm{O} 4$ & $92.81(7)$ \\
\hline $\mathrm{O} 2-\mathrm{Cr} 1-\mathrm{O} 1$ & $89.65(8)$ & $\mathrm{O} 1-\mathrm{Cr} 1-\mathrm{O} 5$ & $173.82(7)$ \\
\hline $\mathrm{O} 3-\mathrm{Cr} 1-\mathrm{O} 1$ & $90.29(7)$ & $\mathrm{O} 6-\mathrm{Cr} 1-\mathrm{O} 5$ & $83.12(7)$ \\
\hline $\mathrm{O} 2-\mathrm{Cr} 1-\mathrm{O} 6$ & $93.66(8)$ & $\mathrm{O} 2-\mathrm{Cr} 1-\mathrm{O} 4$ & $173.53(7)$ \\
\hline $\mathrm{O} 3-\mathrm{Cr} 1-\mathrm{O} 6$ & $175.20(7)$ & $\mathrm{O} 3-\mathrm{Cr} 1-\mathrm{O} 4$ & $82.56(7)$ \\
\hline $\mathrm{O} 1-\mathrm{Cr} 1-\mathrm{O} 6$ & $91.01(7)$ & $\mathrm{O} 1-\mathrm{Cr} 1-\mathrm{O} 4$ & $90.31(8)$ \\
\hline $\mathrm{O} 2-\mathrm{Cr} 1-\mathrm{O} 5$ & $88.80(7)$ & $\mathrm{O} 5-\mathrm{Cr} 1-\mathrm{O} 4$ & $91.89(7)$ \\
\hline $\mathrm{O} 3-\mathrm{Cr} 1-\mathrm{O} 5$ & $95.71(7)$ & & \\
\hline
\end{tabular}

chelating oxalate groups is $91.890(8)^{\circ}$ and the shortest intermolecular chromium-chromium is 6.644(1) $\AA$.

The $\mathrm{C}-\mathrm{C}$ bond distances in the oxalate ligand are as expected for single $\mathrm{C}-\mathrm{C}$ bond [1.556(3) and 1.554(3) $\AA$ for $\mathrm{C} 1-\mathrm{C} 2$ and $\mathrm{C} 3-\mathrm{C} 4$, respectively]. The bond length of the peripheral and inner $\mathrm{C}-\mathrm{O}$ bonds compare well with those reported for other oxalate complexes. The shorter values being due to the greater double bond character of the free $\mathrm{C}-\mathrm{O}$ bonds. ${ }^{21}$

The 3,5-dimethylpyrazole ligand is planar and the

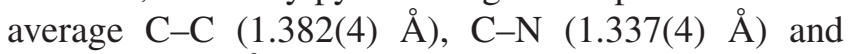
$\mathrm{N}-\mathrm{N}(1.347(4) \AA)$ bond lengths, and the average angles $\left(108^{\circ}\right)$ within the rings are in a good agreement with those reported in the literature for 3,5-dimethylpyrazole coordinated metal complexes. ${ }^{22-24}$ The cation mean deviations are of $0.003 \AA$ from the plane. Both methyl group substituents are almost coplanar with the pyrazole rings.

The structure of the title compound consists of mixed layers of complex anion formed by $\left[\mathrm{Cr}\left(\mathrm{C}_{2}\right.\right.$ $\left.\left.\mathrm{O}_{4}\right)_{2}\left(\mathrm{H}_{2} \mathrm{O}\right)_{2}\right]^{-}$and free water molecules parallel to (101) plan intercalated by sheet of organic cations $\left(\mathrm{C}_{5} \mathrm{H}_{9} \mathrm{~N}_{2}\right)^{+}$ (figure 2). The cohesion of the structure is ensured by strong $\mathrm{O}-\mathrm{H} . . . \mathrm{O}$ and $\mathrm{N}-\mathrm{H} . . . \mathrm{O}$ hydrogen bonds ${ }^{25,26}$ and by van der Walls interactions leading to a threedimensional network.

In this compound $\left[\mathrm{Cr}\left(\mathrm{C}_{2} \mathrm{O}_{4}\right)_{2}\left(\mathrm{H}_{2} \mathrm{O}\right)_{2}\right],\left(\mathrm{C}_{5} \mathrm{H}_{9} \mathrm{~N}_{2}\right)^{+}$ cation and uncoordinated water molecules are joined through $\mathrm{O}-\mathrm{H} . . . \mathrm{O}, \mathrm{N}-\mathrm{H} . . . \mathrm{O}$ hydrogen bonds [length d(D...A) and angle, (D-H...A) vary from 2.615(3) to $2.988(3) \AA$ and 161 to $174(3)^{\circ}$, respectively] into 3D supramolecular networks (table S1 in Supplementary Information). Hence, the uncoordinated water molecules (O11, O12 and O13) play a role as both acceptors and donors while the coordinated water molecules (O1 and $\mathrm{O} 2)$ act only as donors, forming an anions-anions interaction type.

For the oxalate groups, the peripheral carboxylateoxygen atoms $\mathrm{O} 8, \mathrm{O} 9$ and $\mathrm{O} 10$ are the only acceptors.

The $\left[\mathrm{Cr}\left(\mathrm{C}_{2} \mathrm{O}_{4}\right)_{2}\left(\mathrm{H}_{2} \mathrm{O}\right)_{2}\right]$ and $\left(\mathrm{C}_{5} \mathrm{H}_{9} \mathrm{~N}_{2}\right)^{+}$are connected via $\mathrm{N}-\mathrm{H}$...O hydrogen bonds that link the amino $\mathrm{N} 1-\mathrm{H} 1$ group to the free $\mathrm{O} 10$ oxalato $\mathrm{O}$ atoms, forming an cations-anions interaction type by connecting the positive and the negative layers (figure 3 ).

An additional stability of the crystal is afforded by $\pi-\pi$ interactions between the aromatic rings of the cation $\left(\mathrm{C}_{5} \mathrm{H}_{9} \mathrm{~N}_{2}\right)^{+}$to form layers parallel to the bc plane of the unit cell (figure 2). The centroid-centroid distance between two adjacent organic rings of 3,5dimethylpyrazole, $\mathrm{Cg} 1 . . \mathrm{Cg} 1=4.826 \AA \mathrm{Cg} 1$ is the centroid of the N1-N2-C5-C7-C8 (figure 4).

All these interactions link the layers together forming a three-dimensional network and reinforcing the cohesion of the ionic structure. 


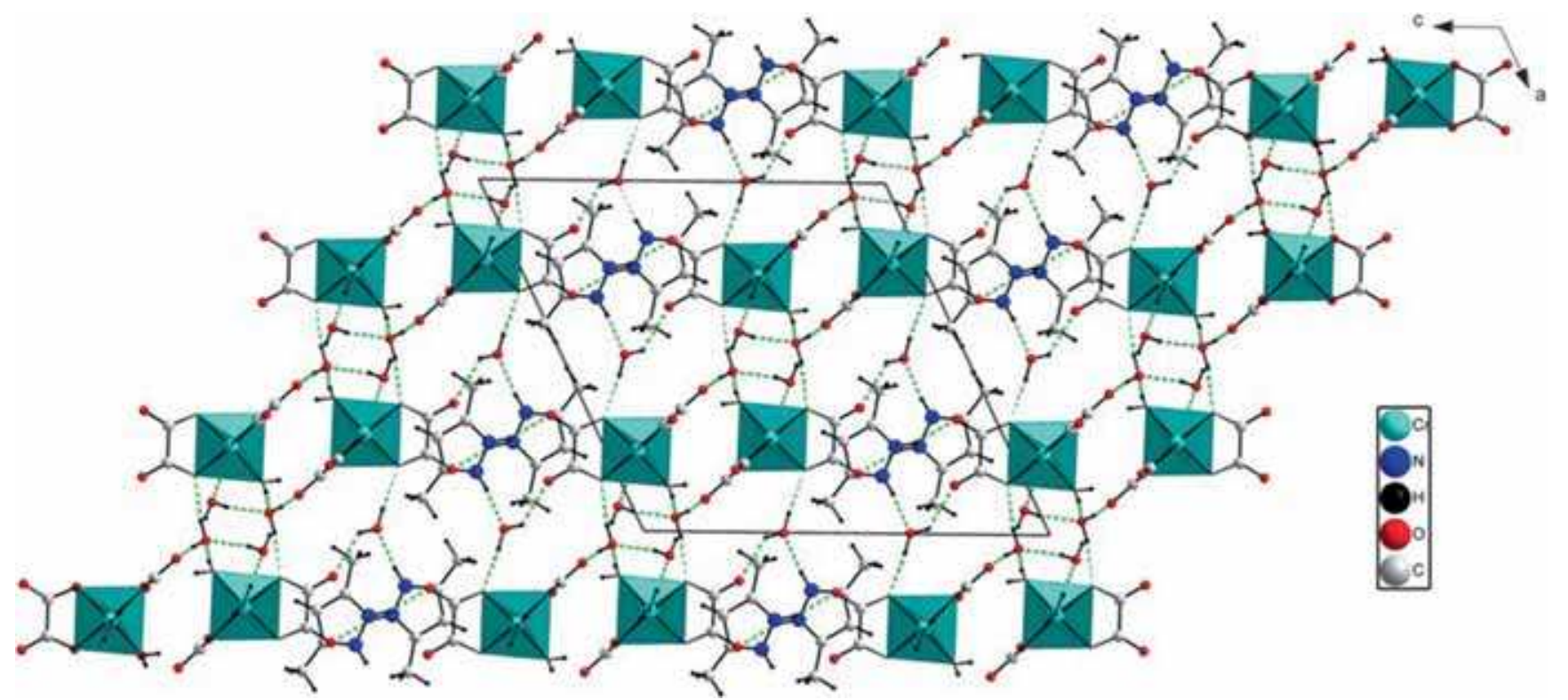

Figure 2. Projection of the $\left(\mathrm{C}_{5} \mathrm{H}_{9} \mathrm{~N}_{2}\right)\left[\mathrm{Cr}\left(\mathrm{C}_{2} \mathrm{O}_{4}\right)_{2}\left(\mathrm{H}_{2} \mathrm{O}\right)_{2}\right] .3 \mathrm{H}_{2} \mathrm{O}$ structure along the baxis showing the hydrogen bonded network.

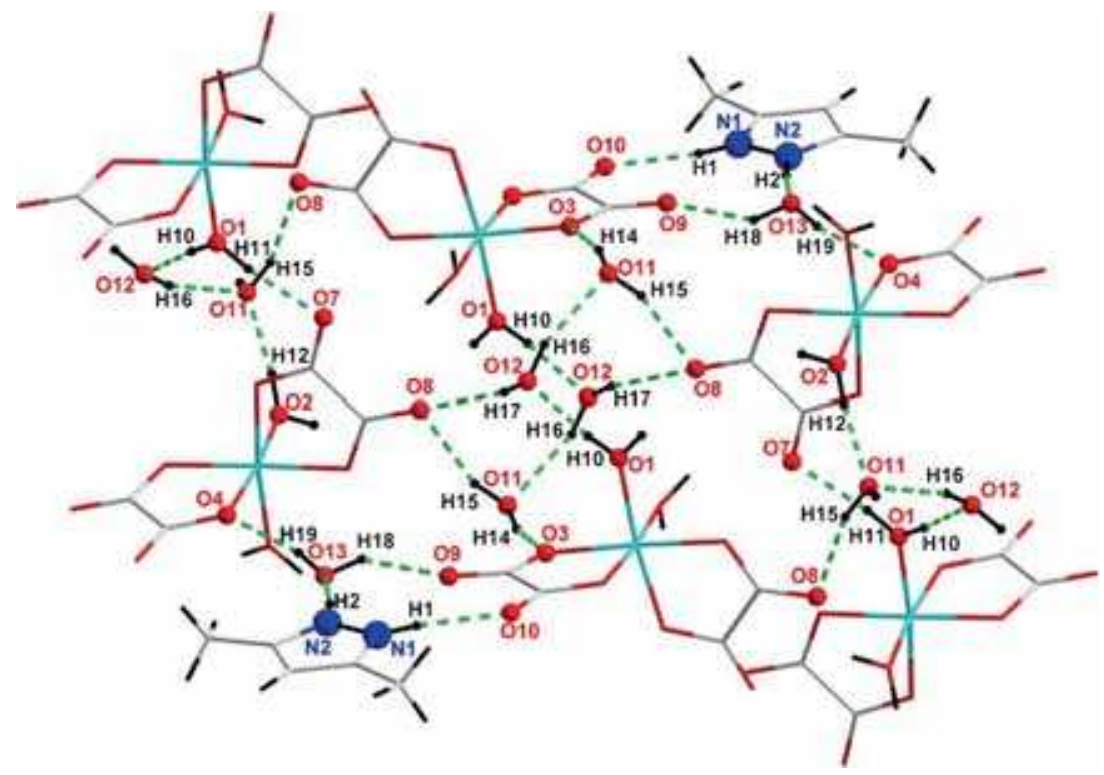

Figure 3. Fragments of the molecular structure of $\left(\mathrm{C}_{5} \mathrm{H}_{9} \mathrm{~N}_{2}\right)\left[\mathrm{Cr}\left(\mathrm{C}_{2} \mathrm{O}_{4}\right)_{2}\right.$ $\left.\left(\mathrm{H}_{2} \mathrm{O}\right)_{2}\right] .3 \mathrm{H}_{2} \mathrm{O}$ showing hydrogen bonding interactions.

\subsection{Crystal morphology}

The crystal growth morphology has an enormous impact during the material processing stage. This is why the knowledge of the growth features and morphological properties of the molecular crystals are of crucial importance for understanding and exploiting many of their physico-chemical properties. For this, rationalization of the relationships between crystal morphology and the arrangement of atoms in the bulk crystal lattice is of great interest. Figure S1 shows a good agreement between the observed and predicted morphologies by the Morphology module in Accelrys Materials Studio version 6.0 software. ${ }^{27}$ It is predicted that the dominating faces are $(-10-1),(-101)$ as well as $(-110)$ and (01-1).

\subsection{Vibrational spectra}

The infrared spectra of $\left(\mathrm{C}_{5} \mathrm{H}_{9} \mathrm{~N}_{2}\right)\left[\mathrm{Cr}\left(\mathrm{C}_{2} \mathrm{O}_{4}\right)_{2}\left(\mathrm{H}_{2} \mathrm{O}\right)_{2}\right]$. $3 \mathrm{H}_{2} \mathrm{O}$ (figure $\mathrm{S} 2$ ) shows the existence of oxalate 


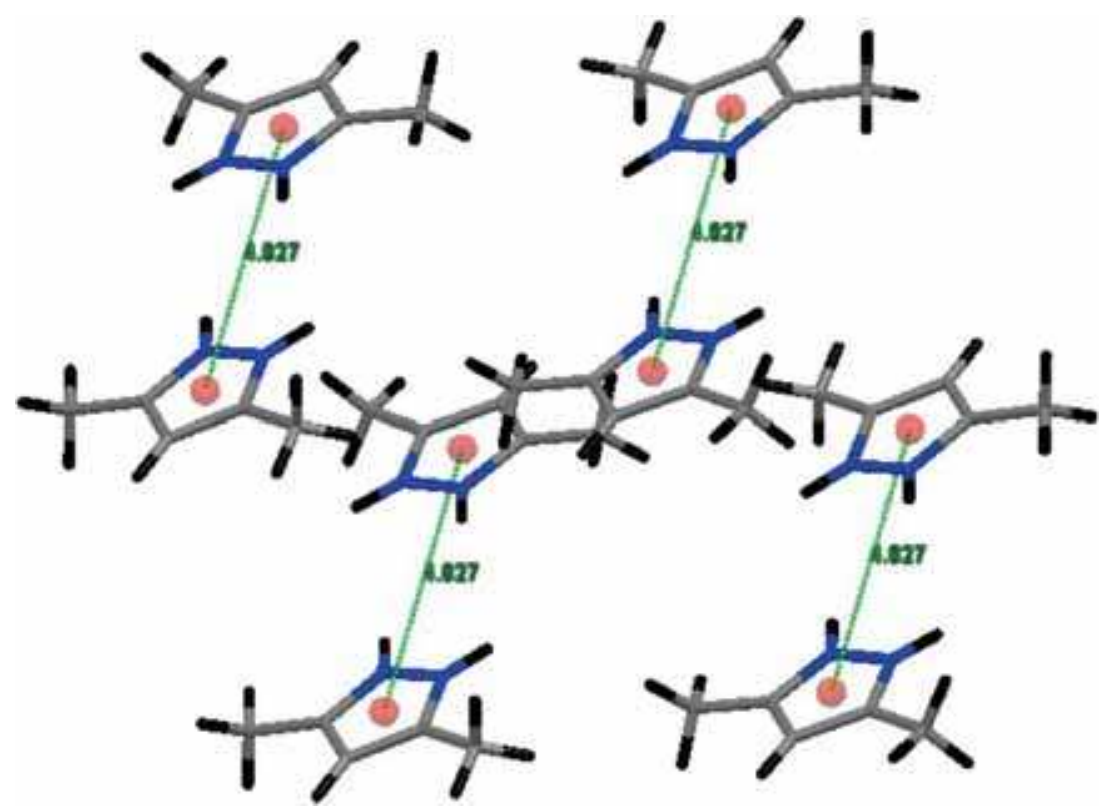

Figure 4. Perspective view of the molecular structure showing $\pi-\pi$ stacking interactions between the neighboring aromatic cations indicated by broken lines.

dianion, 3,5-dimethylpyrazole as well as $\mathrm{H}_{2} \mathrm{O}$. In fact, characteristic bands of the oxalate ligand appear at 1700,1380 and $801 \mathrm{~cm}^{-1}$ for $v_{\text {asy }}(\mathrm{C}=\mathrm{O}), v_{\mathrm{sy}}(\mathrm{C}=\mathrm{O})$ and $\delta(\mathrm{C}=\mathrm{O})$, respectively. ${ }^{28}$ The region of the $v_{\text {asy }}(\mathrm{C}=\mathrm{O})$ and $v_{\mathrm{sy}}(\mathrm{C}=\mathrm{O})$ stretching vibrations of the oxalate group often shows slight differences owing to diverse coordination modes. The split bands are generally characteristic of the bidentate oxalate groups as terminal ligands. ${ }^{29}$ The strong and broad absorption band at $3600-3200 \mathrm{~cm}^{-1}$ is attributed to the $v(\mathrm{OH})$ stretching vibrations of water molecules in the crystal lattice as well as $v(\mathrm{C}-\mathrm{H})$ and $v(\mathrm{~N}-\mathrm{H}) .{ }^{30}$ Additionally, the peaks located at 1430,1276 and $1150 \mathrm{~cm}^{-1}$ are assignable to $v(\mathrm{C}=\mathrm{C}), v(\mathrm{C}-\mathrm{N})$ and $v(\mathrm{C}-\mathrm{C})$ stretching vibrations of pyrazole groups. ${ }^{31}$ Furthermore, the band at about 550 $\mathrm{cm}^{-1}$ is characteristic for $\mathrm{Cr}-\mathrm{O}$ stretching vibration. ${ }^{32}$

\subsection{Electronic spectra}

As shown in figure 5 the electronic spectrum of the title compound recorded in water at room temperature exhibits a strong band in the ultraviolet region, which may be assigned to charge transfer transition, and two bands in the visible, one at $17730 \mathrm{~cm}^{-1}$ and the other at $23923 \mathrm{~cm}^{-1}$ corresponding to ${ }^{4} \mathrm{~A}_{2 \mathrm{~g}} \rightarrow{ }^{4} \mathrm{~T}_{2 \mathrm{~g}}\left(v_{1}\right)$ and ${ }^{4} \mathrm{~A}_{2 \mathrm{~g}} \rightarrow{ }^{4} \mathrm{~T}_{1 \mathrm{~g}}(\mathrm{~F})\left(v_{2}\right)$ transitions, respectively. These results are in good agreement with those mentioned in the literature. ${ }^{33,34}$ The very strong absorption in the UV region of the spectra at $280 \mathrm{~nm}$ may be assigned to ligand to metal charge transfer. ${ }^{35}$

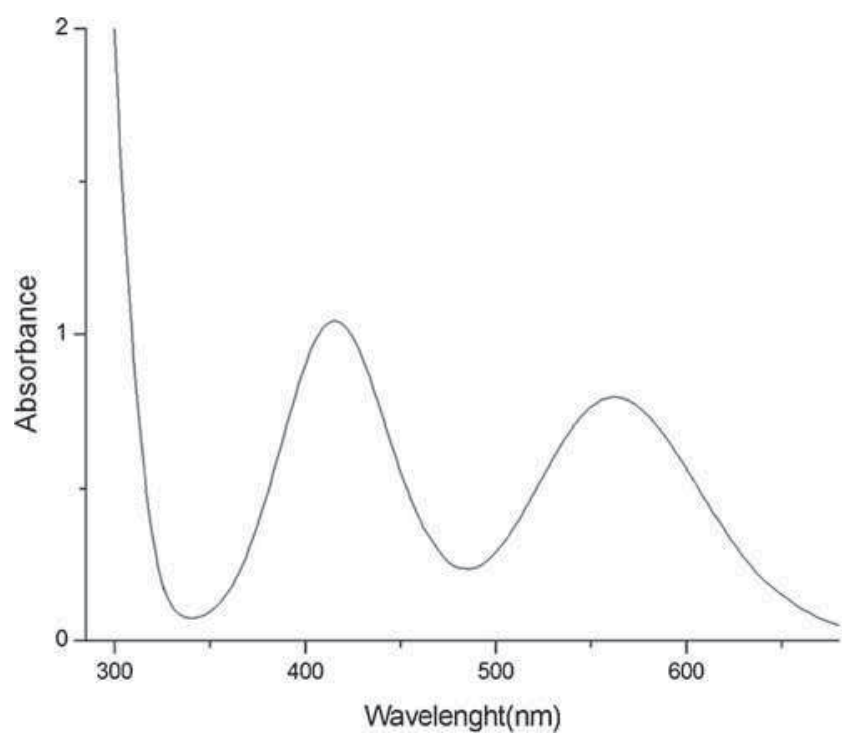

Figure 5. UV-Visible spectrum of $\left(\mathrm{C}_{5} \mathrm{H}_{9} \mathrm{~N}_{2}\right)\left[\mathrm{Cr}\left(\mathrm{C}_{2} \mathrm{O}_{4}\right)_{2}\right.$ $\left.\left(\mathrm{H}_{2} \mathrm{O}\right)_{2}\right] \cdot 3 \mathrm{H}_{2} \mathrm{O}$. Concentration, $6.0 \times 10^{-3} \mathrm{M}$, path length, $1 \mathrm{~cm}$.

The values of $\mathrm{Dq}$ and $\mathrm{B}$ were found as $1773 \mathrm{~cm}^{-1}$ and $546 \mathrm{~cm}^{-1}$, respectively. These parameters were calculated from the values of $v_{1}$ and $v_{2}$ according to the formula of electronic transition energy. ${ }^{36,37}$

$$
\begin{aligned}
v_{1}= & 10 \mathrm{D} \\
v_{2}= & 7.5 \mathrm{~B}+15 \mathrm{Dq} \\
& \quad-1 / 2\left(225 \mathrm{~B}^{2}+100 \mathrm{Dq}^{2}-180 \mathrm{Dq} \cdot \mathrm{B}\right)^{1 / 2}
\end{aligned}
$$




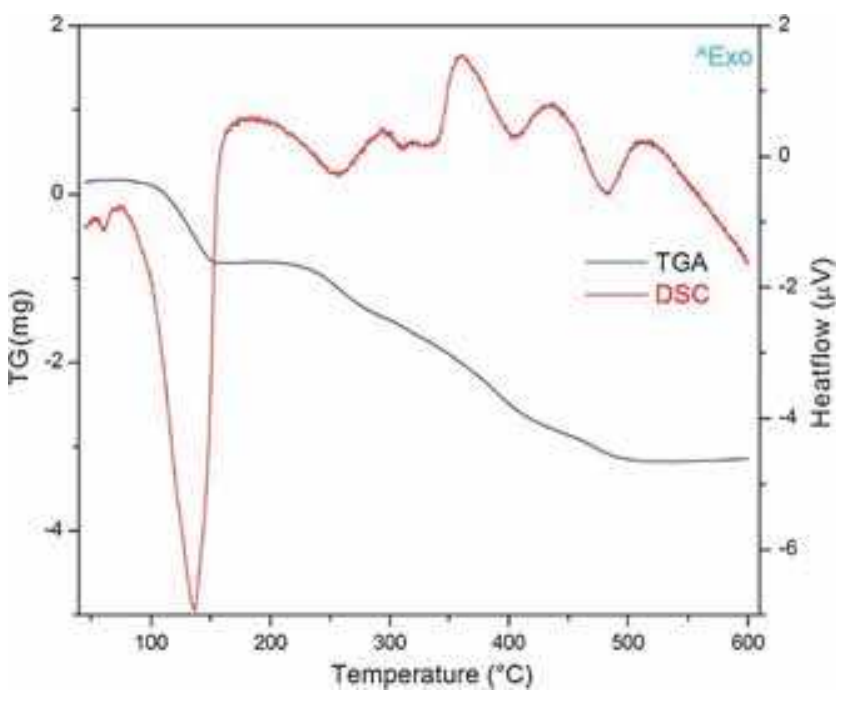

Figure 6. Thermogravimetric curves (TG and DSC) of $\left(\mathrm{C}_{5} \mathrm{H}_{9} \mathrm{~N}_{2}\right)\left[\mathrm{Cr}\left(\mathrm{C}_{2} \mathrm{O}_{4}\right)_{2}\left(\mathrm{H}_{2} \mathrm{O}\right)_{2}\right] .3 \mathrm{H}_{2} \mathrm{O}$. Initial weight $=5 \mathrm{mg}$.

$$
\begin{aligned}
v_{3}= & 7.5 \mathrm{~B}+15 \mathrm{Dq} \\
& +1 / 2\left(225 \mathrm{~B}^{2}+100 \mathrm{Dq}^{2}-180 \mathrm{Dq} . \mathrm{B}\right)^{1 / 2}
\end{aligned}
$$

The third spin allowed transition, ${ }^{4} \mathrm{~A}_{2 \mathrm{~g}} \rightarrow{ }^{4} \mathrm{~T}_{1 \mathrm{~g}}$ (P) $\left(v_{3}\right)$, is predicted to appear at $v_{3}=39312 \mathrm{~cm}^{-1}$ (254 nm).

\subsection{X-ray powder diffraction analyses and thermal analyses}

In order to check the purity, X-ray powder diffraction measurement was carried out at room temperature. As shown in figure $\mathrm{S} 3$, the similarity of the calculated pattern and the observed one confirms the high purity level of the synthesized phase.

The TG/DSC of the title compund were performed under Ar atmosphere, in the temperature ranging from $40-600^{\circ} \mathrm{C}$, with a heating rate of $10^{\circ} \mathrm{C} \mathrm{min}^{-1}$. The obtained thermograms are shown in (figure 6).

The overall weight loss amounts to $71.04 \%$ and is based on the stoichiometry of the starting material $\left(\mathrm{C}_{5} \mathrm{H}_{9} \mathrm{~N}_{2}\right)\left[\mathrm{Cr}\left(\mathrm{C}_{2} \mathrm{O}_{4}\right)_{2}\left(\mathrm{H}_{2} \mathrm{O}\right)_{2}\right] .3 \mathrm{H}_{2} \mathrm{O}$ (formula weight: 415.26 g.mol $\left.{ }^{-1}\right)$. In the temperature range $60-150^{\circ} \mathrm{C}$, the TG trace shows a $21.44 \%$ loss in weight, suggesting that the compound loses five water molecules in one step which is consistent with the calculated weight loss of $21.67 \%$. The result is in agreement with the structure which contains five water molecules. In addition, the salt loses weight between $150-470^{\circ} \mathrm{C}$, indicating the decomposition of the oxalate groups and the organic part of the material. But no clear plateaus were reached in these stages and the total weight loss is equal to $49.6 \%$.

\section{Conclusions}

Single crystals of the new salt $\left(\mathrm{C}_{5} \mathrm{H}_{9} \mathrm{~N}_{2}\right)\left[\mathrm{Cr}\left(\mathrm{C}_{2} \mathrm{O}_{4}\right)_{2}\right.$ $\left.\left(\mathrm{H}_{2} \mathrm{O}\right)_{2}\right] .3 \mathrm{H}_{2} \mathrm{O}$ were grown from an aqueous solution at ambient temperature. The crystal structure of the title compound has been characterized by single crystal X-ray diffraction and confirmed by XRPD, IR, UVVisible and TG-DSC techniques. A three-dimensional network was shown to be generated by intermolecular $\mathrm{N}-\mathrm{H} . . \mathrm{O}$ and $\mathrm{O}-\mathrm{H}$...O hydrogen-bonding interactions involving the cation, the complex anion and the lattice water molecules and by $\pi-\pi$ interactions between the rings of 3,5-dimethylpyrazole. Estimated morphology with the BFDH model is in agreement with the observed crystal shape. IR data and the thermal analysis have allowed to check the number of water molecules as well as the nature of connections to the network of these molecules, confirming the result of the structural study.

\section{Supplementary Information}

Crystallographic data and full lists of bond lengths and angles have been deposited with the Cambridge Crystallographic Data Centre, CCDC No. 1005075. Copies of this information may be obtained free of charge from The Director, CCDC, 12 Union Road, CAMBRIDGE, CB2 1EZ, UK (fax:+44-1223-336-033; email:deposit@ccdc.cam.ac.uk or http://www.ccdc. cam.ac.uk).

Hydrogen-bonding geometry (table S1), estimated morphology with BFDH model (a), and growth single crystal of the complex (b) (figure S1), infrared spectra of the complex (figure S2) and experimental and simulated PXRD of the complex (figure S3) are available at www.ias.ac.in/chemsci.

\section{References}

1. Tang X L, Lin H L, Xin J H, Liu F, Li M and Zhu X P 2013 J. Nanomater. 2013616501

2. Kuppler R J, Timmons D J, Fang Q R, Li J R, Makal T A, Young M D, Yuan D, Zhao D, Zhuang $\mathrm{W}$ and Zhou H C 2009 Coord. Chem. Rev. 2533042

3. Jia H P, Li W, Ju Z F and Zhang J 2007 J. Mol. Struct. $\mathbf{8 3 3} 49$

4. Marinescu G, Andruh M, Lloret F and Julve M 2011 Coord. Chem. Rev. 255161

5. Tuna F, Pascu G I, Sutter J P, Andruh M, Golhen S, Guillevic J and Pritzkow H 2003 Inorg. Chim. Acta. 342 131

6. Klein O, Aguilar-Parrilla F, Lopez J M, Jagerovic N, Elguero J and Limbach H H 2004 J. Am. Chem. Soc. 126 11718

7. Castaneda J P, Denisov G S, Kucherov S Y, Schreiber V M and Shurukhina A V 2003 J. Mol. Struct. 66025 
8. Janiak C 2000 J. Chem. Soc. Dalton Trans. 3885

9. Barszcz B 2005 Coord. Chem. Rev. 2492259

10. Hollo B, Tomic Z D, Pogany P, Kovacs A, Leovac V M and Szecsenyi K M 2009 Polyhedron 283881

11. Dridi R, Cherni S, Zid M F and Driss A 2013 Acta Crystallogr., Sect. E: Struct. Rep. Online 96 m 489

12. Sheldrick G M 1997 SHELX-97, Program for crystal structure refinement (University of Göttingen: Germany)

13. Brandenburg K 2003 Visual crystal structure information system, Version 3.0 (University of Bonn: Germany)

14. Marchivie M, Guionneau P, LeÂtard J F and Chasseau D 2003 Acta Crystallogr., Sect. B: Struct. Sci. 59 m479

15. Castillo O, Luque A and Román P 2001 J. Mol. Struct. 570181

16. McCann M, Casey M T, Derveux M, Curan M and McKee V 1997 Polyhedron 162741

17. Belombe M M, Nenwa J and Emmerling F 2009 Z. Kristallogr. New Cryst. Struct. 224239

18. Nenwa J, Belombe M M, Ngoune J and Fokwa B P T 2010 Acta Crystallogr., Sect. E: Struct. Rep. Online 66 $\mathrm{m} 1410$

19. Cherif I, Abdelhak J, Zid M F and Driss A 2011 ActaCrystallogr., Sect. E: Struct. Rep. Online $67 \mathrm{~m} 1648$

20. Kahlenberg V, Wertl W, Tobbens D M and Schottenberger H 2011 Z. Anorg. Allg. Chem. 6371371

21. Marinescu G, Andruh M, Lescouezec R, Munoz M C, Cano J, Lloret F and Julve M 2000 New. J. Chem. 24527

22. Jin S W, Huang Y, Wang D Q, Fang H, Wang T, Fu P and Ding L 2013 Polyhedron 6010

23. Li J, Xing Y H, Zhao H Y, Li Z P, Wang C G, Zeng X Q, Ge M F and Niu S Y 2009 Inorg. Chim. Acta. 3622788
24. Chakravorty S, Platts J A and Das B K 2011 Dalton Trans. 4011605

25. Brown I D 1976 Acta Crystallogr., Sect. A: Found. adv. $32 \mathrm{~m} 24$

26. Blessing R H 1986 Acta Crystallogr., Sect. B: Struct. Sci. $42 \mathrm{~m} 613$

27. Materials Studio version 6.02011 (Accelrys Software Inc.: San Diego)

28. Marinescu G, Lescouezec R, Armentano D, De Munno G, Andruh M, Uriel S, Llusar R, Lloret F and Julve M 2002 Inorg. Chim. Acta. 33646

29. Li W, Jia H P, Ju Z F and Zhang J 2008 Dalton Trans. 5350-5357

30. Marinescu G, Andruh M, Lescouezec R, Munoz M C, Cano J, Lloret F and Julve M 2000 New. J. Chem. 24 527

31. Krishnakumar V, Jayamani N and Mathammal R 2011 Spectrochim. Acta, Part A 791959

32. Nakamoto K 1978 In Infrared and Raman spectra of Inorganic and coordination compounds 3rd edition (New York: John Wiley)

33. Choi J H, Oh I G, Suzuki T and Kaizaki S 2004 J. Mol. Struct. 69439

34. House D A and McKee V 1984 Inorg. Chem. 23 4237

35. Zurek J M, Martin J and Paterson M J 2012 J. Chem. Phys. 137034308

36. Meyer K, Bendix J, Bill E, Weyhermuller $\mathrm{T}$ and Weighardt K 1998 Inorg. Chem. 375180

37. Lever A B P 1984 In Inorganic Electronic Spectroscopy, 2nd edition (Amsterdam: Elsevier) 